\title{
Development of High Antioxidant Red Palm Oil Cake as a Potential Functional Food
}

\author{
Rini Harianti ${ }^{*}$, Sri Anna Marliyati², Rimbawan², Dadang Sukandar ${ }^{2}$ \\ ${ }^{1}$ Program Study of Public Health, STIKES Al-Insyirah Pekanbaru, Pekanbaru 28155 \\ ${ }^{2}$ Department of Community Nutrition, Faculty of Human Ecology, Bogor Agricultural University, \\ Bogor 16680
}

\begin{abstract}
This study aimed to develop high antioxidant cake product with red palm oil (RPO) content to substitute the use of margarine as a potential functional food. This study used a complete randomized design with four levels of RPO substitution for margarine, namely F0 (0:100), F1 (80:20), F2 (90:10), and F3 $(100: 0)$. Organoleptic results showed that high antioxidant cake F3 was best in which also contained the highest RPO addition level. The high antioxidant cake F3 had yellow colour, hardness of $650.67 \mathrm{gf}$, bulk density of $0.27 \mathrm{~g} / \mathrm{ml}, 4.31 \%$ moisture, $1.48 \%$ ash, $21.66 \%$ fat, $9.76 \%$ protein, $62.80 \%$ carbohydrate, $40.74 \mathrm{ppm} / 100 \mathrm{~g} \beta$-carotene, and the $470.44 \mathrm{mg} / 100 \mathrm{~g}$ antioxidant activity. Thus the product can be categorized as high in $\beta$-carotene. Therefore, this product has a potential to be a functional food options, especially for atherosclerosis prevention.
\end{abstract}

Keywords: antioxidant activity, $\beta$-carotene, high antioxidant cake, product development, red palm oil

\section{INTRODUCTION}

Atherosclerosis is a progressive inflammatory disease characterized by excessive deposition of cholesterol in the arterial wall (Wallert et al. 2014). The incidence of atherosclerosis is often associated with the risk of coronary heart disease (CHD). The individuals with subclinical atherosclerosis were at greatest risk of experiencing Coronary Vascular Disease (CVD), the risk is three times higher than individual without atherosclerosis (Robinson et al. 2009). Unhealthy lifestyle including high dietary intake of fat can trigger onset of atherosclerosis (Wallert et al. 2014), therefore there is a need for certain compounds that can increase the body's antioxidant status.

Red Palm Oil (RPO) is a result of processing and refining Crude Palm Oil (CPO), RPO's contents of carotenoids is $500-700 \mathrm{ppm}$ ( $\beta$-carotene 50-56.02 ppm, $\alpha$-carotene 30-35.16 ppm), vitamin $\mathrm{E}$ in form of tocopherols is $500-600 \mathrm{ppm}$ ( $\alpha$-tocopherol 129-215 ppm, $\beta$-tocopherol 22$37 \mathrm{ppm}, \gamma$-tocopherol $19-32 \mathrm{ppm}, \delta$-tocopherol $10-16 \mathrm{ppm})$, and tocotrienols is $1000-1200 \mathrm{ppm}$ ( $\alpha$-tocotrienol 44-73 ppm, $\beta$-tocotrienol 44-73 ppm, $\gamma$-tocopherol 262-437 ppm, $\delta$-tocopherol 70-117 ppm) (Mba et al. 2015). The presence of $\beta$-carotene and other functional components make RPO has a great potential as functional food ingredient (Yuliasari et al. 2014) which have been used in local snacks such as spring rolls, curry puff and doughnut (Tkw et al. 2012) majority of whom had normal body mass index for age (BMI-for-age).
Che et al. (2014) stated that palm oil is an excellent source of two major phytochemicals, namely vitamin E (tocopherols, tocotrienols) and carotenoids, both of which are fat-soluble, act as a potent biological antioxidants, protect against oxidative stress, prevent plaque formation and cardiovascular diseases through modulating redox sensitive steps in disease progression. A number of epidemiological studies have revealed that an increased consumption of diet rich in carotenoids is correlated with a diminished risk of several degenerative disorders, including cardiovascular disease (Stahl \& Sies 2003).

The interaction of $\beta$-carotene and vitamin $E$ led to a diverse biological effect from free radical scavenging to modulation of signal transduction that associated with reduced risk of CHD (Vrolijk et al. 2015). Addition of RPO into a diet is also known to remove the plaque formation in the arteries, thereby preventing the formation of blockages because of the antioxidant content.

Indonesia is one of the countries with largest palm oil production in the world and the production is increasing every year, but RPO-based food in Indonesia is still limited. The availability of abundant palm oil as the basic ingredient of RPO can be used as the basis for $\beta$-carotene source added in processed foods. This effort can in turn improves the quality of the processed food as functional food to prevent atherosclerosis.

Against this backdrop, product development in the form of high antioxidants cake was carried out. The cake product was selected because it contains a possibility of RPO use as mar-

*Corresponding Author: tel: +6285265339465; email: riniharianti37@gmail.com 
garine substitute. RPO has a potential as margarine substitute material because it has fatty acids compositions and has produced relatively similar colours and textures for the end product. In addition, the cake can be consumed as snacks for all ages, so it has good functional properties for health.The objectives of the study were to develop hi gh antioxidant cake product with red palm oil content as a functional food, to evaluate the acceptance, physical and chemical properties of selected high antioxidant cake, and to analyse the potential high antioxidant cake in the $\beta$-carotene content and the antioxidant activity.

\section{METHODS}

\section{Design, location, and time}

The study design was completely randomized design experimental study done in the laboratory with four levels of RPO substitution for margarine, namely F0 (0:100), F1 (80:20), F2 (90:10), and F3 (100:0). This research was conducted in April-September 2017. RPO production was conducted in SEAFAST-CENTRE IPB pilot plan which was the result from processing and refining Crude Palm Oil from PT. Salim Ivomas Pratama Tbk, Jakarta.

The formulation of high antioxidant cake and the preparation were conducted in processing and food experiment laboratory Department of Community Nutrition IPB, the organoleptic test were done in organoleptic laboratory Department of Community Nutrition IPB, the physical properties analysis were conducted in food science and technology laboratory Department of Food Science and Technology IPB, the analysis of nutritional and $\beta$-carotene content were conducted in Saraswanti Laboratory Indo Genetech Bogor.

\section{Materials and tools}

The raw materials used to manufacture the high antioxidant cake products were wheat, instant yeast, sugar, liquid milk, eggs, margarine, RPO and salt. The chemicals required for analysis were (1) reagents for analysis of the product nutrient content a) hexane solvents for fat content analysis using Soxhlet direct extraction method, b) $\mathrm{NaOH}(30 \%), \mathrm{H}_{3} \mathrm{BO}_{3}, \mathrm{H}_{2} \mathrm{SO}_{4}$, methyl red and methylene blue indicator for protein content analysis using micro Kjeldahl method; (2) reagents for $\beta$-carotene analysis using HPLC methods were standard solutions of $\beta$-carotene, $95 \%$ ethanol, $50 \% \mathrm{KOH}$; (3) reagents for analysis of antioxidant activity using DPPH method were hexane, ethyl acetate, methanol, acetate buffer solution, standard solution of vitamin C, DPPH $0.5 \mathrm{mM}$.

The tools used for products manufacture were mixers, ovens, and scales while for the organoleptic test were plastic plate, serving tray, and label. Tools utilized for nutrient content analysis and physical properties test were scales, erlenmeyer, glass cup, dropper and micro, porcelain cup, vortex, burette, filter paper, centrifuges, oven, furnace, Soxhlet, Kjeldahl flask, hotplate, steam bath, desiccator, analytical scales, spectrophotometer, Chroma Meter, Texture Analyser. Equipment for $\beta$-carotene content analysis and antioxidant activity analysis were scales, micro pipettes, vortex, measuring flask, centrifuges, evaporator, Erlenmeyer, spectrophotometer, and High Performance Liquid Chromatography (HPLC) tools.

\section{Procedures}

Product making. The formula of product referred to Marjan et al. (2016) with slight modification. The formulation of dried cake was done by taking into account the adequacy level of vitamin A based on Recommended Dietary Alowance (RDA). The subjects were men aged 35-45 years who had the adequacy level of vitamin A of $600 \mu \mathrm{g} /$ day. This age group belongs to the general population who has the adequacy level of vitamin A of $600 \mu \mathrm{g} /$ day (BPOM 2016). $1 \mu \mathrm{g} \mathrm{RE}$ is equivalent to $6 \mu \mathrm{g} \beta$-carotene thus the adequacy level of $\beta$-carotene in the general population is $3600 \mu \mathrm{g} /$ day. RPO levels used in the formulation were $0 \%(\mathrm{~F} 0), 80 \%(\mathrm{~F} 1), 90 \%(\mathrm{~F} 2)$, and $100 \%$ (F3) (Table 1).

The cake making begun with well mixed flour, yeast, and sugar. Further liquid milk and eggs were added into the mix, then mixed it from low to medium speed (speed 1-3) until the dough was flatted. RPO and salt were added last and then mix the dough again up to dull. The dough then was left to stand for 10 minutes. The dough was divided into $20 \mathrm{~g}$, rounded portions and let stand again for 10 minutes. Then each dough was flattened using a rolling pin, rounded again before they were arranged on a baking sheet and put

Table 1. Formulation of cake

\begin{tabular}{|c|c|c|c|c|}
\hline \multirow[t]{2}{*}{ Materials (g) } & \multicolumn{4}{|c|}{$\begin{array}{l}\text { The amount of material in each } \\
\text { formula }(\mathrm{g})\end{array}$} \\
\hline & F0 & F1 & F2 & F3 \\
\hline Wheat & 250 & 250 & 250 & 250 \\
\hline Instant yeast & 5 & 5 & 5 & 5 \\
\hline Sugar & 50 & 50 & 50 & 50 \\
\hline Liquid milk & 120 & 120 & 120 & 120 \\
\hline Egg & 50 & 50 & 50 & 50 \\
\hline Margarine & 63 & 12.6 & 6.3 & 0 \\
\hline RPO & 0 & 50.4 & 56.7 & 63 \\
\hline Salt & 3 & 3 & 3 & 3 \\
\hline Total of dough & 541 & 541 & 541 & 541 \\
\hline
\end{tabular}

J. Gizi Pangan, Volume 13, Number 2, July 2018 
into proofing chamber for 30 minutes. The oven was heated to $170^{\circ} \mathrm{C}$ and the cake was baked for 15 minutes. After that, the cakes were split in half and baked again in the oven at $130^{\circ} \mathrm{C}$ for $40 \mathrm{mi}$ nutes.

Evaluation of acceptance, physical and chemical properties of selected products. The acceptance evaluation of selected high antioxidant cake products was done through hedonic test (colour, aroma, taste, texture, and overall) and hedonic quality test (overall colour, aroma, sweet taste, bite texture, and aftertaste) involving 35 semi-trained panellists, who are students in Department of Community Nutrition FEMA, IPB. The hedonic test was performed using product preferences on a scale of 1-7 representing (1) strongly dislikes, (2) dislikes, (3) somewhat dislikes, (4) neutral, (5) rather, (6) likes, and (7) is very fond. Analysis of physical properties include hardness, colour degree, and bulk density using Muchtadi et al. (2010). The nutrient content analysis was done through the test of proximate, including ash content using Gravimetry method, moisture content of oven method, protein content of micro Kjeldahl method, fat content of Soxhlet method (AOAC 2005), carbohydrate content by difference and total energy by calculation.

Potential high antioxidant cake products in $\beta$-carotene content and antioxidant activity. Measurement of $\beta$-carotene content of the product was done by HPLC method and the total antioxidant was determined by DPPH scavenging activity method and expressed in AEAC (ascorbic acid equivalent antioxidant capacity) (Molyneux 2004; Damayanthi et al. 2010) .

\section{Data analysis}

Data processing and analysis were done with Microsoft Excel and IBM SPSS Statistics software. Data analysis was done descriptively as well as inferential at significance level 0.05 by using ANOVA. If the effect was the found significant $(p<0.05)$ further analysis was then conducted with Duncan test.

\section{RESULTS AND DISCUSSION}

\section{Development of high antioxidant cake pro- ducts}

The initial stage of development of the high antioxidant cake products was done by trying some standard formulas before further formulation was done. The preparation of high antioxidants cake was done by adding RPO into the initial dough. RPOs used in high antioxidant cake formulas are F0 (0\%), F1 (80\%), F2 (90\%) and F3 (100\%). Each formula took into account the level of $\beta$-carotene contained in each formula and panellist acceptance of a high antioxidant cake product. The high antioxidant cake based on a predetermined formula are presented in Figure 1.

\section{Organoleptic properties of high antioxidant cake products}

Organoleptic tests were performed to obtain the most accepted and preferred antioxidant cake formula by panellists through the hedonic and hedonic quality test (Table 2 and 3 ).

Colour. The first sensory attributes was colour (Chairil et al. 2014), the hedonic test results showed that the average value for the cake colour attribute were ranging from 3.82 to 5.47 (usual). The highest preference value (likes) was found in high antioxidant cake F2 and the lowest (slightly disliked) value was F0. The average value of panellist's preference for colour quality ranged from 2.66-4.59 (yellowish-yellowish-orange cream).

The variance analysis showed that difference in RPO addition had significant effect $(p<0.05)$ to panellist's favourite level of cake colour attribute. Further Duncan test results showed that panellist's preference for high antioxidant cake colour F2 and F3 were not significantly different, but the high antioxidant cake F0 and F1 were significantly different from F2 and F3. In addition, the results of variance also showed that difference of RPO addition had significant effect $(p<0.05)$ on colour quality of high antioxidant cake. Further Duncan test results showed that colour on high antioxidant cake F0 was significantly different from F1, F2, and F3. This preference toward F2 and F3 were due to the $\beta$-carotene content of RPO. In addition to its antioxidant function, RPO can act as natural dye on any formula of high antioxidant cake. The initial product colour/control (F0) without RPO addition was beige. The addition of RPO, making the product colour yellow-brownish and golden yellow thus increased panellist preferences for selected products.

Aroma. Another sensory parameters to be considered in choosing food is aroma. The results of hedonic test showed that average value of panellist's favourite level on high antioxidant cake aroma attributes ranging from 4.23-4.71 (ordinary-rather like). The highest preferred value (somewhat like) was found in high antioxidant cake F2 and the lowest (common) favourite value was found in high antioxidant cake F1. The value of higher antioxidant cake aroma showed that lower quality of aroma was very strong, while the higher value showed that quality of aroma was very weak. The results of analysis showed that average value of panellist favourability on high antioxidant cake aroma quality ranged from 4.534.94 (normal-rather weak).

The results of variance showed that difference of RPO addition had significant effect 


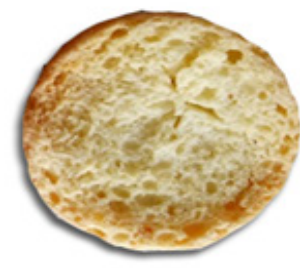

(a)

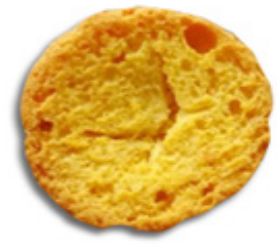

(b)

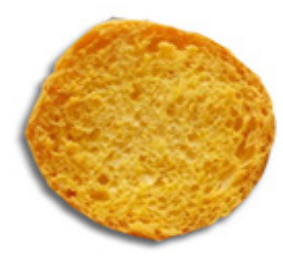

(c)

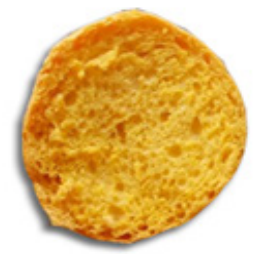

(d)

Figure 1. High antioxidant cake. (a) F0, (b) F1, (c) F2, and (d) F3

Table 2. Results of hedonic test of high antioxidant cake

\begin{tabular}{cccccc}
\hline \multirow{2}{*}{ Formula } & \multicolumn{5}{c}{ Attributes } \\
\cline { 2 - 6 } & Colour & Aroma & Taste & Texture & Overall \\
\hline F0 & $3.82^{\mathrm{a}}$ & $4.27^{\mathrm{ab}}$ & $4.56^{\mathrm{a}}$ & $4.46^{\mathrm{a}}$ & $4.44^{\mathrm{a}}$ \\
F1 & $4.40^{\mathrm{b}}$ & $4.23^{\mathrm{a}}$ & $4.55^{\mathrm{a}}$ & $4.72^{\mathrm{a}}$ & $4.59^{\mathrm{a}}$ \\
F2 & $5.47^{\mathrm{c}}$ & $4.71^{\mathrm{b}}$ & $5.12^{\mathrm{b}}$ & $5.18^{\mathrm{b}}$ & $5.26^{\mathrm{b}}$ \\
F3 & $5.10^{\mathrm{c}}$ & $4.57^{\mathrm{ab}}$ & $4.85^{\mathrm{ab}}$ & $5.25^{\mathrm{b}}$ & $5.02^{\mathrm{b}}$ \\
\hline
\end{tabular}

Description: Attribute scale, namely $1=$ very unlikely to 7 = very like; different letters in the same column show significant differences $(\mathrm{p}<0.05)$

Table 3. Results of hedonic quality test of high antioxidant cake

\begin{tabular}{cccccc}
\hline \multirow{2}{*}{ Formula } & \multicolumn{5}{c}{ Attributes } \\
\cline { 2 - 6 } & Overall colour & Langu aroma & Sweet taste & Texture & Aftertaste \\
\hline F0 & $2.66^{\mathrm{a}}$ & $4.89^{\mathrm{a}}$ & $4.47^{\mathrm{a}}$ & $4.46^{\mathrm{a}}$ & $4.55^{\mathrm{a}}$ \\
F1 & $4.59^{\mathrm{b}}$ & $4.53^{\mathrm{a}}$ & $4.80^{\mathrm{a}}$ & $4.73^{\mathrm{ab}}$ & $4.36^{\mathrm{a}}$ \\
F2 & $4.01^{\mathrm{b}}$ & $4.94^{\mathrm{a}}$ & $4.77^{\mathrm{a}}$ & $6.18^{\mathrm{b}}$ & $4.62^{\mathrm{a}}$ \\
F3 & $4.30^{\mathrm{b}}$ & $4.72^{\mathrm{a}}$ & $4.90^{\mathrm{a}}$ & $5.12^{\mathrm{ab}}$ & $4.43^{\mathrm{a}}$ \\
\hline
\end{tabular}

Description: The overall colour of the scale $1=$ beige to 7 = brownish orange, Langu aroma scale $1=$ very strong to $7=$ very weak, sweet taste scale $1=$ not very sweet to $7=$ very sweet, texture scale $1=$ very hard up to $7=$ very crisp, Aftertaste scale 1 $=$ very bitter to $7=$ very not bitter ; different letters in the same column show significant differences $(\mathrm{p}<0.05)$

$(\mathrm{p}<0.05)$ to panellist's favourite level on high antioxidant cake aroma attribute. Further Duncan test results showed that level of fondness the high antioxidant cake F1 and F2 were significantly different, but high antioxidant cake F0, F2 and F3 were not significantly different. The results of variance showed that difference of RPO addition had no significant effect $(p>0.05)$ on the high antioxidant cake scent quality in each formula. Further Duncan test results showed that scent on all formulas were not significantly different. The existing aroma was suspected because RPO does not undergo deodorization process. In addition, the presence of beta-ionon compounds contained in RPO gives a distinctive aroma to RPO (Ketaren 2012).

Taste. Taste is a major factor which can determine the acceptance of each product and success of a product on the market (Awasthi et al. 2012). The results of hedonic test showed that average value of panellist's favourite level on high antioxidant cake taste attributes ranging from 4.55-5.12 (usual). The highest preferred value 66 (likes) was given on high antioxidant cake F2 and the lowest (usual) favourite value was given on high antioxidant cake F1. The lower of taste score means the less quality of sweetness, while the higher of score means that the taste quality is sweeter. The results showed that panellists gave average quality of taste ranging from 4.47 to 4.90 (normal-rather sweet).

The results of variance showed that difference of RPO addition had significant effect $(p<0.05)$ to panellist's favourite level on high antioxidant cake sweet taste attribute. Further Duncan test results showed that level of fondness for high antioxidant cake taste F1 and F2 were significantly different, but for high antioxidant cake F0, F1, with F3 were not significant, as well as the high antioxidant cake F2 with F3. The results of variance showed that difference of RPO addition had no significant effect $(\mathrm{p}>0.05)$ on the high quality of antioxidant cake taste in each formula. Further Duncan test results showed that sweet taste on all the formulas was not significantly different. The sense of acceptance by panellists

J. Gizi Pangan, Volume 13, Number 2, July 2018 
was proposed to be due to addition of sugar that causes sweetness to the cakes. In addition, the flavour of the cakes can be influenced by addition of salt to dough, so the resulting sweetness was not too strong.

The result of hedonic quality was applied to measure the aftertaste attribute which is the taste sensation left on tongue after food is consumed or the impression felt after sensing is done (Widiantoko \& Yunianta 2014). The resulting aftertaste of this product was focused on weird taste of the ingredients that remain on tongue after consuming the product, one of which is bitterness. The taste arises due to the oil oxidation process that produce aldehyde, ketone, and aromatic compounds that have a rancid odor (Ketaren 2012).

The results of aftertaste analysis showed that average value of panellist's preference to high quality aftertaste attribute of high antioxidant cakes ranging from 4.36-4.62 (ordinaryrather not bitter). The highest (slightly non-bitter) favourite value was found in high antioxidant cake F2 and lowest (common) favourite value was found on the high antioxidant cake F1. The result of variance showed that difference of RPO addition had no significant effect $(p>0.05)$ on high antioxidant cake aftertaste quality. Further Duncan test results showed that quality of aftertaste on all formulas were not significantly different.

Texture. The preference to a product can be determined from the texture. The existence of texture changes can change the taste and smell that arise (Winarno 2000). The results of the hedonic test showed that average value of panellist's favourite level on the high antioxidant cake texture attributes ranging from 4.46 to 5.25 (usual). The highest favourite value (likes) was given to the high antioxidant cake F3 and the lowest (usual) favourite value was given to the high antioxidant cake F0. The cake texture value showed that lower quality of texture is very hard, while the higher values showed that the quality of texture was very crunchy. The results showed that average value given by panellists to the high antioxidant cake texture quality ranges from 4.46 to 5.12 (usual-very crunchy).

The results of variance showed that difference of RPO addition had significant effect $(p<0.05)$ to panellist's favourite level on high antioxidant cake texture attribute. Duncan's advanced test results showed that texture attribute on the high antioxidant cake F0, F1 were significantly different with F2 and F3, but for the high antioxidant cake F2 and F3 were not significantly different, as did the high antioxidant cake F0 and $\mathrm{F} 1$. The result of variance showed that difference of RPO addition had significant effect $(\mathrm{p}<0.05)$ on high antioxidant cake texture qua-lity. Further Duncan test results showed that texture attribute on high antioxidant cake F0 with F2 were significantly different, but for high antioxidant cake F1, F3, and F2 were not significantly different. The increasing level of RPO in the product results in a favourable level of texture with a crispier texture. There is a change in texture to be crispier as amount of RPO increased and decreased in the amount of margarine used.

Overall. The results of hedonic test showed that average value of panellist's favourite level on the overall attribute of high antioxidant cake ranging from 4.44 to 5.26 (usual). The highest favourite value (likes) was given to the high antioxidant cake F2 and the lowest (usual) favourite value was given to the high antioxidant cake F0. The result of variance showed that difference of RPO addition had significant effect $(p<0.05)$ to panellist's favourite level to the overall attribute of high antioxidant cake. Duncan's test results showed that overall attribute of high antioxidant cake F0, F1 were significantly different with F2 and F3, but the formula F2 and F3 were not significantly different.

Selected high antioxidant cake products on organoleptic tests were obtained based on the largest mean value and overall attributes, as well as taking into account value and extent of highest RPO addition on each of high antioxidant cake formulas. If the four formulas were compared by their favoured levels, then the high-antioxidant cake with an additional RPO of $90 \%$ (F2) and $100 \%$ (F3) were selected. However, the results of Duncan's test showed that no significant difference between the high antioxidant cake F2 and F3 as overall, so considering the highest RPO addition level, the high antioxidant cake F3 (100\%) was selected.

\section{Characteristics of physical properties selected high antioxidant cake products \\ Colour degrees. The high brightness co-} lour (L) of the high antioxidant cake was 65.60. The higher the $\mathrm{L}$ value, the brighter the product colour. It is thought to be caused by carotenoid content pigments that dissolve in RPO thus giving a reddish-yellow colour. The more RPO contained in product, the brighter the colour, because of the carotenoid pigment (Dwiyanti et al. 2014). The high antioxidant cake has a value (a red chromatic value) of 4.77 , the value of $b$ (yellowish) of 59.88, and the value of c (sharpness of colour) of 60.06. Based on Munsel diagram, the ${ }^{0} \mathrm{Hue}$ value on the high antioxidant cake was 85.50 (quadrant I) which showed yellow colour objectively. The ${ }^{0} \mathrm{Hue}$ value indicates the product's yellow colour due to the addition of the RPO. 
Hardness. The principle of hardness measurement is to give a certain magnitude of force to the material. Harder product means that the product is less crisp (Amalia \& Kusharto 2013). The value of hardness in high antioxidant cake was 650.67 gf, compared to the organoleptic results, high antioxidant cake fall into crunchy category.

Bulk density. The bulk density of a material is influenced by the shape, size and inversely related to the moisture content of the material, the lower the moisture, the higher the density (Safitri \& Purwantiningrum 2014). The results showed that high antioxidant cake had a bulk density value of $0.27 \mathrm{~g} / \mathrm{ml}$. The value of bulk density for products made of starch ranges from 0.56 to 0.62 $\mathrm{g} / \mathrm{ml}$ (Lalel et al. 2009). The bulk density of high antioxidant cake is smaller than starchy products. This proposed to be caused by high moisture content of product produced in this study. Materials with low bulk density require a wider area than materials with higher bulk density for the same weight, thus inefficient in terms of storage and packaging (Ade-Omowaye \& Adebiyi 2008).

\section{The nutrient content of high cake antioxidants cake selected}

The result of the nutrient contents analysis of high antioxidant cake selected based on proximate test are presented in Table 4.

Table 4. Nutritional content of selected antioxidant cakes

\begin{tabular}{lc}
\hline \multicolumn{1}{c}{ Component } & Result \\
\hline Moisture (\%) & 4.31 \\
Ash (\%) & 1.48 \\
Protein (\%) & 9.76 \\
Fat (\%) & 21.66 \\
Carbohydrate (\%) & 62.80 \\
Total energy (kcal/100 g) & 485.12 \\
\hline
\end{tabular}

Moisture content. Moisture is a critical component of food that determined its storage management as well as its appearance, texture and taste (Winarno 2008). Higher moisture content in product can increase the microbial activity, so that the resulting products are not long lasting. Moisture content of the high antioxidant cake was $4.31 \%$ and qualified within the Indonesian National Standard (SNI) 01-2973-2011 for cookies products, with the maximum of 5\% in moisture content. The low moisture content of the product has a positive impact because it can extend the shelf life of product (Muchtadi et al. 2010).

Ash content. Mineral content in a food and the content of inorganic substances in food can be measured trough the ash content (Winarno 2008). The higher ash content value of the material, the higher mineral content in it. The ash content of foodstuff also reflects the quality of food related to certain metal contaminants. The results showed that the ash content of high antioxidant cake was $1.48 \%$ and meet the quality requirement of SNI 01-2973-2011 for cookies product, in which the maximum is $2 \%$.

Protein content. The protein content is measured through average nitrogen content in food. The results showed that protein content of high antioxidant cake was $9.76 \%$, and still in accordance to the quality requirement of SNI 012973-2011 for cookies product, that is at least $5 \%$.

Fat content. The addition of fat in the food gives a delicious flavour and softer texture. Result of analysis obtained the fat content of the high antioxidant cake was $21.66 \%$. The high fat content of the high antioxidant cake is thought to be due to the addition of $100 \%$ RPO in the selected formula. The fat content of the high antioxidant cakes still meet the quality requirements of SNI 01-2973-2011 for cookies products (cookies), which is at minimum of $9.5 \%$.

Carbohydrate content. Carbohydrates is a source of energy and has an important role in determining characteristics of food such as flavour, colour, texture and others. Carbohydrate content was calculated by difference. The results showed that carbohydrate content of high antioxidant cake was $62.80 \%$. Carbohydrate content of products has not reached the range of quality requirements SNI 01-2973-2011, which is at least $70 \%$. This is presumably because the calculation of carbohydrate levels done by difference is influenced by other nutrient components, The higher other nutrient components, the carbohydrate levels will be lower, so other nutrients that have high enough contribution such as fat that mostly derived from RPO will affect carbohydrate content of the product.

Total energy content. The energy content of high antioxidants cake is obtained by converting proteins, fats and carbohydrates into energy. Based on NRV for the general age group, the energy requirements per day is $2,150 \mathrm{kcal}$. The product is reccomended as snacks and consumed twice a day. The proportion in once consumed of snacking is $10-15 \%$ from total daily energy requirement. It means that $430 \mathrm{kcal}$ of energy is required to meet the energy needs. The results showed that the calculation of total energy content of high antioxidant cake was $485.12 \mathrm{kcal} / 100$ g. This energy content has fulfilled the proportion for snacks food from the total daily energy requirement. 


\section{Potential high cake antioxidant products se- lected}

Content of $\beta$-carotene. RPO is an alternative source rich in $\beta$-carotene, $\alpha$-carotene and tocopherols in which are believed to have beneficial health effects, one of which acts as an antioxidant and is an important singlet-oxygen-scavenger in the human body (Sommerburg et al. 2015). Making cake products using RPO is intended to meet the need of beta-carotene. Based on the analysis of $\beta$-carotene content of RPO used in products manufacture amounted to $214.13 \mathrm{ppm}$. The levels of $\beta$-carotene did not different greatly from $\beta$-carotene RPO levels in Ayeleso et al. (2012) study that is equal to $220 \mathrm{ppm}$. The amount of RPO added to the baking dough was as much as $63 \mathrm{~g}$ out of total $541 \mathrm{~g}$ of cake dough. The amount of RPO added to cake product mixture are adjusted to $\beta$-carotene contained in RPO.

BPOM RI regulation No. 13/2016 regulates the monitoring of the claims on labels and advertisements of processed foods. The food is considered to be source of vitamins or minerals if it meets $15 \%$ of Nutrient Reference Values (NRV) per $100 \mathrm{~g}$ (in solid form) and considered to be high in vitamins or minerals if it meets $30 \%$ of NRV per $100 \mathrm{~g}$ (in solid form). The subjects were men aged 35-45 years who had the adequacy level of vitamin A of $600 \mu \mathrm{g} / \mathrm{day}$. This age group belongs to the general population who has the adequacy level of vitamin A of $600 \mu \mathrm{g} /$ day. However, this regulation do not regulate the claim of bioactive compound such as $\beta$-carotene. We then applied the regulation to make the standard of $\beta$-carotene using the equation of vitamin $A$ and $\beta$-carotene (1 $\mu \mathrm{g} R E=6 \mu \mathrm{g} \beta$-carotene). We got $1,080 \mu \mathrm{g} /$ day of $\beta$-carotene as cut-off to state the food high in $\beta$-carotene.

The amount of $\beta$-carotene expected from this dried cake to meet the claim of high in vitamin A, 30\% of NRV, is $180 \mu \mathrm{g} /$ day (BPOM 2016). $1 \mu \mathrm{g} \mathrm{RE}$ is equivalent to $6 \mu \mathrm{g} \beta$-carotene thus the adequacy level of $\beta$-carotene in the general population is $3600 \mu \mathrm{g} /$ day. $\beta$-carotene content of selected dried cake was $40.74 \mathrm{ppm}$ equivalent to $4074 \mu \mathrm{g} / 100$ grams of food products. Levels of $\beta$-carotene in selected dried cake products had met the claim of high in $\beta$-carotene because it exceeded $1,080 \mu \mathrm{g}$.

Antioxidant activity. An antioxidant activity analysis was performed using the DPPH method expressed in mg AEAC/100 g. The results showed that antioxidant activity of the high antioxidant cake was $470.44 \mathrm{mg} / 100 \mathrm{~g}$, meaning that every $100 \mathrm{~g}$ of high antioxidant cake products had antioxidant activity equivalent to 470.44 $\mathrm{mg}$ of vitamin C. Antioxidant activity of high antioxidant cake products was thought to be caused by carotenoids, $\beta$-carotene, and vitamin $\mathrm{E}$ con- tained in RPO. These compounds are included in compounds that have an antioxidant role (Sayuti \& Yenrina 2015). As an antioxidant compounds, $\beta$-carotene can increase endurance, reduce the risk of stroke, and prevent the development of atherosclerosis disease by inhibiting plaque formation (Agarwal et al. 2012).

The high antioxidant activity of this product offers an alternative for functional food in the form of convenient snacks to prevent atherosclerosis. High intake of $\beta$-carotene as an antioxidants does not reduce all causes of cardiovascular disease, but these $\beta$-carotene antioxidants are able to inhibit LDL oxidation damage and inhibit plaque wall thickening when taken regularly (Kritchevsky et al. 2002; Wallert et al. 2014).

\section{CONCLUSION}

The high antioxidant cake F3 was best based the highest organoleptic tests and also contained the highest RPO addition level. Thus the product can be categorized as high in $\beta$-carotene. Therefore, this product has a potential to be a functional food alternative, especially for atherosclerosis prevention.

\section{ACKNOWLEDGEMENTS}

The authors would like to thank Directorate of Research and Community Service of Directorate General of Research and Development Strengthening of the Ministry of Research, Technology and Higher Education through Competitive Grant of Superior Strategic Research of Superior Research Program of Higher Education which has funded this research according to Contract Number: 011/SP2H/LT/DRPM/IV/2017. We wish to thank PT. Salim Ivomas Pratama who providing the crude palm oil for this research.

\section{REFERENCES}

Agarwal M, Parameswari RP, Vasanthi HR, Das DK. 2012. Dynamic action of carotenoids in cardioprotection and maintenance of cardiac health. Molecules 17(4):47554769.

[AOAC] Association of Official Analytical Chemist. 2005. Official Method of Analysis of Assosiation of Official Analytical Chemist. Ed ke-18. Arlington: AOAC Inc.

Ade-Omowaye O, Adebiyi IF. 2008. Evaluation of tigernut (Cyperus esculentus)-wheat composite flour and bread. African Journal of Food Science (2):87-91.

Amalia F, Kusharto CM. 2013. Formulasi flakes pati garut dan tepung ikan lele dumbo (Clarias gariepinus) sebagai pangan kaya 
energi protein dan mineral untuk lansia. 8(2):137-144.

Awasthi I, Pornoor S, Maitrayee T, Vandana T. 2012. Development of soy fortified high protein and high calorie supplementary biscuits. IJSR 3(1):51.

Ayeleso AO, Oguntibeju OO, Brooks NL. 2012. Effects of dietary intake of red palm oil on fatty acid composition and lipid profiles in male wistar rats. Afr J Biotechnol 11(33):8275-8279.

[BPOM RI] Badan Pengawas Obat dan Makanan Republik Indonesia. 2016. Keputusan Kepala Badan Pengawas Obat dan Makanan Republik Indonesia Nomor 9 Tahun 2016 about Acuan Label Gizi. Jakarta: BPOM RI.

[BPOM RI] Badan Pengawas Obat dan Makanan Republik Indonesia. 2016. Peraturan Kepala Badan Pengawas Obat dan Makanan RI Nomor 13 Tahun 2016 tentang Pengawasan Klaim pada Label dan Iklan Pangan Olahan. Jakarta (ID): BPOM RI

Chairil MMF, Kustiyah L. 2014. Formulasi flakes berbasis pati garut dengan fortifikasi zat besi $(\mathrm{Fe})$ untuk perbaikan status besi remaja putri. J Gizi Pangan 9(2).

Che I, Che A. 2014. Oil palm phenolics and vitamin e reduce atherosclerosis in rabbits. $\mathrm{J}$ Funct Foods 7(1):541-550.

Damayanthi E, Kustiyah K, Mahani K. 2010. Antioxidant activity rice bran higher than tomato juice and the decreasing of total antioxidant activity serum after high antioxidant beverage intervention. J Gizi Pangan 5(3):205-210.

Dwiyanti H, Riyadi H, Rimbawan, Damayanthi E. 2014. Penambahan CPO dan RPO sebagai sumber provitamin a terhadap retensi karoten, sifat fisik, dan penerimaan gula kelapa. J Tekno Industri Pertanian 24(1):28-33

Ketaren S. 2012. Minyak dan Lemak Pangan Jakarta: UI-Press.

Kritchevsky D, Tepper SA, Czarnecki SK, Kalyana S. 2002. Red Palm Oil in experimental atherosclerosis. Asia Pacific J of Clin Nutr $11: 433-S 437$.

Lalel HJD, Abidin Z, Jutomo L. 2009. Sifat fisiko kimia beras merah gogo lokal ende. Jurnal Tekno dan Industri Pangan 20(2):109-116.

Marjan AQ, Marliyati S, Ekayanti I. 2016. Development of food product with red palm oil substitution as an alternative functional food high in beta carotene. J Gizi Pangan 11(2):91-98.

Mba OI, Marie-Josée D, Ngadi M. 2015. Palm oil: processing, characterization and utili- zation in the food industry-a review. Food Biosci 10:26-41.

Molyneux P. 2004. The use of the stable free radical Diphenylpicryl-Hydrazyl (DPPH) for estimating antioxidant activity. SJST 26(12):211-219.

Muchtadi, Tien R, Ayustaningwarno, Fitriyono. 2010. Teknologi Proses Pengolahan Pangan. Bandung: Alfa Beta.

Robinson JG, Kathleen MF, Michael FB, Susan G. 2009. Atherosclerosis profile and incidence of cardiovascular events: a population-based survey. BMC Cardiovascular Disorders $9(\mathrm{Cvd}): 46$.

Safitri Y, Purwantiningrum. 2014. The influence of modified starch's adding for non dairy creamer's product against the Emulsification Stability and the efficiency of sodium caseinate usage. J Pangan dan Agroindustri 1(1p):1-14.

Sayuti K, Yenrina R. 2015. Antioksidan Alami dan Sintetik. Padang: Andalas University Press.

Sommerburg O, Silke De S, Annett M, Cornelia J, Claus-Dieter L, Kalanithi N, Werner S, Wilhelm S, Marcus A. Mall. 2015. Supplementation with red palm oil increases beta-carotene and vitamin a blood levels in patients with cystic fibrosis. Mediators of Inflammation 2015(817127):1-5.

Stahl W, Helmut S. 2003. Antioxidant activity of carotenoids. Molecular Aspects of Medicine 24(6):345-351.

Tkw Ng, Low Cx, Kong Jp, Cho Y1. 2012. Use of red palm oil in local snacks can increase intake of provitamin A carotenoids in young Aborigines children. Mal J Nutr 18(2002):393-397.

Vrolijk MF, Antoon O, Eugène HJMJ, Roger WG, Frederik JVS, Aalt B, Guido RMMH. 2015. The shifting perception on antioxidants: the case of vitamin $E$ and $\beta$-carotene. Redox Biology 4(2015):272-278.

Wallert M, Lisa S, Francesco G, Marc B, Stefan L. 2014. Regulatory metabolites of vitamin $\mathrm{E}$ and their putative relevance for atherogenesis. Redox Biology 2(1):495-503.

Widiantoko RK, Yunianta. 2014. Pembuatan es krim tempe-jahe (kajian proporsi bahan dan penstabil terhadap sifat fisik, kimia, dan organoleptik). Jurnal Pangan dan Agroindustri 2(1):54-66.

Winarno FG. 2008. Kimia Pangan dan Gizi. Bogor: M-Brio Press.

Yuliasari, Shannora, Dedi F, Andarwulan N. 2014. Characteristics of Red Palm Oil nano emulsions enriched with betacarotene. Littri 20(8):111-21. 